\title{
MACHIAVELLIAN POLITICAL MANUAL IN POLITICS: A STUDY OF MALAYSIAN POLITICAL REALISM AS REFLECTED IN PARADOKS
}

\author{
Sohaimi Abdul Aziz \\ School of Humanities, Universiti Sains Malaysia, Pulau Pinang, MALAYSIA \\ Email: soaazz@usm.my
}

Published online: 30 April 2020

To cite this article: Sohaimi Abdul Aziz. 2020. Machiavellian political manual in politics: A study of Malaysian political realism as reflected in Paradoks. Kajian Malaysia 38(1): 1-17. https://doi.org/10.21315/km2020.38.1.1

To link to this article: https://doi.org/10.21315/km2020.38.1.1

\begin{abstract}
Paradoks by Affifuddin Omar is a novel discussing the issue of Malay Muslim politicians who have strayed from the norms and practices of Islam in thought and deed yet are still accepted as leaders by the Malay Muslim community. Albeit a work of fiction, this novel is accurate in its portrayal of the paradox that is Malay realpolitik. Therefore, this article aims to study the political manoeuvres used by some present-day Malay political leaders in carrying out their responsibilities in an attempt to discover why such leaders still enjoy the support of the populace. $A$ reading approach incorporating textual and political contextual analysis will be applied to analyse the novel. Through this analysis, it is found that the Malay political leaders in the novel subscribe to Machiavellian politics, which upholds that "politics have no relation to morals". As a result, upright Malay political leaders in Paradoks such as Ariffin, who strives for justice and adheres to Islamic and moral values, seem to have no place in Malaysian politics. This situation is exacerbated when the Malay community is more concerned over sensationalised sexual issues than most alarming issues such as corruption and abuse of power. Eventually, these unworthy leaders still command the support of the people, although they are corrupted and immoral beings. As such, the novel presents an image of a Malay Muslim population that has lost its moral compass despite an outward appearance of adhering to the tenets of the religion. This is the paradox, and this is the reality presented in the novel.
\end{abstract}

Keywords: Machiavellian political manual, Malaysian politics, Islamic values 


\section{INTRODUCTION}

A novel and its context are inseparable. The context of a novel is a reflection of its author and his environment combined. Paradoks is a political novel which reflects the relationship between the author and his political environment. This relationship makes Paradoks important in the context of contemporary Malay political novels. The author of Paradoks, Affifuddin Omar is a Malay politician-turned novelist. He was an active member of the dominant political party in Malaysia known as the United Malay National Organisation (UMNO) which became the leading party in the Alliance Party (Parti Perikatan) in 1957 subsequently changing its name to the National Front (Barisan Nasional) in 1973; a coalition of political parties that has ruled Malaysia from independence in 1957 until 2018. The author's true involvement with politics started with the Malaysia General Election in 1986 when he won the Padang Terap parliamentary seat, after which he was elected as UMNO Division Chief for the District of Padang Terap in 1990. Subsequently, he was appointed as the Chairman of the National Front of Padang Terap District and a member of the Supreme Council of UMNO for the term 1993/1996. He was later appointed as Deputy Minister for two important ministries, namely the Ministry of Finance (1995-1999) and the Ministry of Human Resources (1999). He also served as Parliamentary Secretary to the Ministry of Finance in 1994 (http://www .mykedah2.com/20hall_fame/202_9_03.htm). In other words, his involvement as a key leader of the ruling party and his experience as Deputy Minister of two ministries presents an important, personal context for the novel Paradoks with respect to Malaysian political leadership. Although the elements of creativity as part of the creative process in writing Paradoks gives an imaginative dimension to the story, the backdrop of the Malaysian political scenario is difficult to ignore. Besides Paradoks, Affifuddin had also written several other Malay novels previously, such as Odisi Anak Kampar (2011), Dendam (2011), Seri Dewi Malam (2012) and Konspirasi (2016). However, Paradoks is his most realistic political novel to date.

\section{MALAY POLITICS}

What is politics? Politics is to acquire and implement the activities of governing communities in a particular state or country. Those involved in political activities are known as political leaders or politicians. They are influential in determining public policy and decision-making. They are also a concern in designing and implementing those policies (William 1981). The key question here is, how do real life political leaders execute their responsibilities in such a position? This depends on the practice of the political system. For example, through the democratic system, 
political leaders gain their position through a selection system, such as the electoral system, and decision-making is based on the consensus of the majority. When political leaders adopt an autocratic system on the other hand, they are chosen through coercion, and political decisions are made at their own whim without regard for the majority, or instruments of higher authority such as parliament. Such political systems are basically based on a certain political manual. Politics in this article, however, refers exclusively to partisan politics, electoral politics and political leadership.

Politics shapes us all and literature is not spared from it. We, as well as creative writers, cannot escape being shaped by political decisions, big or small, far or near. Politics has become one of the subject matter in literature since the emergence of oral literature because we live in a world of political engagement. Politics has attracted local creative writers such as Affifudin Omar and many others, especially the Malay political players. The raw materials for creative writers are found in their surroundings, their society which cannot escape the snare of political decisions and events. In other words, these writers are not only telling the stories of Malay politics that the readers have already known but also to enable the readers to contemplate what they did not know.

There are numerous researches that have been carried out on Malay politics in Malay literature (Zabidin 2010; Sohaimi 2014; Roslan 2005). One of the findings of these previous researches traced back old Malay literary works, such as Sejarah Melayu (Malay Annals), which discusses the politics of traditional Malay society. Sejarah Melayu is considered a profound literary work of Malay literature. Previous research work on this subject has been written by Noor Sulastry Yurni (2014) which discusses the hegemonic practice in Malay politics during the Malacca Malay Sultanate. Hegemony is a situation in which a powerful group imposes its influence on the people they control. According to Noor Sulastry, the concept of wa'adat (social contract), an important aspect of traditional Malay political culture is introduced in Sejarah Melayu. Through this social contract between Demang Lebar Daun (representing the people) and Seri Teri Buana/Sang Sapurba (representing the authority - the King), the concept of the sovereignty of the King emerged, together with the concept of derhaka (treason) of the people thereby empowering the king to make the laws which subsequently guaranteed his position. The hegemonic practice of the King as the ruler and the people as a protected and governed group can be translated as the loyalty and obedience of the people to the King and thus became a strong cultural practice in Malay politics. In other words, this hegemonic practice established the original framework for Malay political culture and was clearly practised in the days of the Sultanate of Malacca, prior to the period of Western occupation and independence. Thus, feudalism became an important characteristic of Malay politics. 
Feudalism continues to exert influence on Malay political thought from the time of the Malacca Sultanate to the post-independence era and continues even until today. The Malays' submissive nature towards their Kings and leaders has never changed. The obsessiveness and loyalty of the Malay community towards their King, English advisors, and local leaders has thrived and has become a lynchpin of Malay community life. Although resistance towards feudalism has been contained, with the influence of political movements, attempt to challenge this hegemonic practice have occurred albeit fictitiously, as reflected in several Malay novels. Because of the ingrained hegemony, resistance has only occurred in the form of metaphor or symbol as depicted in Putera Gunung Tahan and Anak Mat Lela Gila by Ishak Haji Muhammad. These two novels discuss the political struggle against the British colonisers and feudalism on a purely symbolic level. In Putera Gunung Tahan, the weakness of the king in handling the greed of Western colonialists has been criticised and in the Anak Mat Lela Gila, materialism as a byproduct of colonialism was seen as an agent to destabilise the hegemonic practice (Sohaimi 2014).

Feudalism has also been implicated by Ahmad Boestamam who produced several political novels such as Kabus Pagi (1958), Pacar Merah Malaya (1959), Konfrantasi (1967) and Rumah Kaca Digegar Gempa (1969). He wrote around 10 political novels in the 1950s and 1960s. Based on his novels, his political thought was studied by the likes of Zabidin (2010). Ahmad Boestamam discusses Malay politics within the contexts of nationalism, anti-colonialism and socialism. As a novelist who was very much inclined towards socialism, he acknowledges the lower classes in the hegemonic practices of the Malay community as an important group whose voices should be heeded. Besides being a writer, Ahmad Boestamam was also a leftist politician who embraced socialism. He was the founder of several political parties such as Parti Rakyat Malaysia and the Malayan Peoples' Socialist Front under whose banner he was elected as Member of Parliament for Setapak, Kuala Lumpur in the 1959 General Election. Although Ahmad Boestamam discusses Malay politics outside the context of feudalism, the hegemonic practice since the period of Malacca Sultanate remains intact.

In the context of the post-independence era, especially in the 1970s, more literary works on Malay politics have been published, such as Kawin-Kawin, a novel by Azizi Haji Abdullah. In Kawin-Kawin, hegemonic practice in contemporary Malay community is reflected between two political parties that have different ideologies, nationalism and Islam. Members of the two political parties could not be united due to differences in political ideology thereby creating political tension. This is also the result of hegemonic practice by the ruling party which is based on Malay nationalism. The nationalist political party is portrayed as dominating over the Islamic political party. The subject of hegemonic practice which is based on a political structure of the two groups in which one group dominates the others 
indirectly is also relevant in Paradoks, the novel discussed in this article. The ruling party which dominates the people is so powerful that it is above the rule of law. Leaders of the ruling party or the coalition became arrogant and forgot that their role is to serve the people. Consequently, corruption creeps in and its leaders are sullied to the core and thereby posing a serious concern to creative writers such as Affifuddin Omar.

Besides Affifuddin, the more contemporary Malay political novelist is the late Shahnon Ahmad. He was a member of an opposition party, PAS (Parti Islam Se-Malaysia or Pan-Malaysian Islamic Party). He was elected as a member of Parliament for Sik, Kedah in the 1999 General Election. His inclination towards politics can be detected in his earlier novels such as Menteri (1967) and Perdana (1969). Shahnon can be regarded as a Malay novelist who had devoted much of his creative energy to contemporary Malaysian politics and one of his novels that has created a stir on the Malaysian political scene is SHIT (1999). SHIT is a Malay satirical political novel, which discusses hegemonic issues in which the ruling class uses all of the political apparatus at its disposal to rule, at the expense of moral and religious values. SHIT is a Malay literary work which discusses the dictatorship of a political leader using vulgar language (Roslan 2005). SHIT is a controversial novel which criticised Mahathir Mohamad, the 7th Malaysian Prime Minister whom Shahnon felt had ruled Malaysia dictatorially. In SHIT, he regards Mahathir Mohamad as "shit". Although SHIT is regarded as a surrealist tale about a dictator, the context of the novel clearly refers to the political environment in which Shahnon was directly involved. Thus, the reality of the novel represents the reality of Malaysian politics. Because of its controversial, SHIT has attracted much attention by literary critics such as Arba'ie Sujud, Salihahs Razak and Siti Rabiatul Adawiah Jaffar reflected in their article titled "Pemikiran politik: Pemimpin dan kepemimpinan dalam novel Shahnon Ahmad" (Political thoughts: Leaders and leadership in Shahnon Ahmad's novel) (2015) which discusses political leadership. Although the political background of SHIT is similar to Paradoks, no study has yet been done to discuss the "political manual" used by Malay politicians to enable themselves to contravene Islamic teachings. The question of obedience, loyalty and obsession with political leaders remains strong. If previously, institutions such as Malay and religious rulers and religions were used, during Mahathir Mohamad's government, the media became a tool of hegemonic agents.

Shahnon Ahmad and Affifudin Omar both share a common characteristic, both were directly involved in Malaysian politics. Although Ahmad Boestamam and Shahnon Ahmad's novels have attracted much attention from Malay literary circles, no study has been done to uncover the "political manual" adopted by these politicians. Thus, this article aims to provide a new perspective on Malay political novels especially Paradoks. Paradoks has been selected for this study because Affifuddin Omar is not only a former member of the Malaysian Parliament, but he 
is also involved directly in Malaysian political governance. So he was closer to the inner circle of the Malaysian ruling politicians compared to Shahnon Ahmad. In other words, although the political era of Shahnon Ahmad and Affifuddin Omar is of the same period, i.e. in the late 1990s, Affifuddin Omar's political experiences as reflected in the novel are more substantial and grounded as compared to Shahnon Ahmad's SHIT. Affifuddin was involved directly with the political policies and their implementation. With the dictatorial rules and actions of his party and the government, not much information and secrets of the goverment were being leaked to the public. During his time in office, Affifudin seemed to obey what he had been asked to do by his boss, the Prime Minister Mahathir Mohamad. Nevertheless, when he was no longer in the political hierarchy, he apparently became more critical towards the goverment albeit in his own way such as writing the novel Paradoks. This novel is so close to Affifuddin's own experience in the context of the modern Malaysian political situation; therefore, analysing Paradoks is one way to unearth the dark side of the Malaysian political scenario which has been kept in the dark for all this time.

\section{THE PRINCE: MANUAL OF POLITICAL REALISM}

Niccolò Machiavelli, an Italian political thinker, wrote and published a book entitled The Prince in 1505. The emergence of the book had ignited much debate. Some said this book acts as a guide or manual to govern and others said that this book was a satire and hence politicians are not supposed to rule as such. Actually, this book was dedicated to Lorenzo de' Medici, a ruler of Florence at the time, in which Machiavelli witnessed some political events such as the French conquest of Italy and the Medici family being driven out. For Machiavelli, only Medici could save Italy from collapse. Indeed, this book was dedicated to Medici with various recommendations for the routes, advantages and disadvantages of each route to obtain political power. He also discussed how to gain and maintain the new state, how to cope with internal uprisings, how to form alliances, and how to maintain strong military power. Machiavelli's discussion focused on autocratic regimes. He argued for the importance of Medici to seize power and contain it so that rule could be maintained. Machiavelli has submitted a treatise on political realism, which is a form of political instruction based on his observations on the actual political practice. This political realism treats politics as a science by commenting on data from scientific history. He dismissed the thinking of medieval Europe that emphasised religious values, moral, ethics and other earthly aspects of life, including administration of a country. Machiavelli's political manual submits to the humanistic nature of political leaders, ignoring the pattern of theology, ethics and norms of decency. For example, a political leader who wishes to achieve 
his political goals needs to unite power and law. The law in this context is manmade law, not the divine law. Hence, political leaders do not hesitate to use coercion, intimidation, religious restrictions and the like to achieve their goals. Despite lacking a philosophical or theoretical framework, this political realism can be used as a guide for political governance (Muhammad Kamlin 1986, 98, 101-103). In other words, Machiavelli has produced a political manual based on actual observations derived from history. This political manual is a manual which proposes an autocratic kind of governance. The line of thinking for Machiavelli's political manual can further be understood in The Dictator's Handbook: Why Bad Behavior is Almost Always Good Politics (2012) by Bruce Bueno de Mesquita and Alastair Smith.

\section{ANALYSING PARADOKS}

Paradoks is a political novel, which narrates the story of political leadership of the ruling party and a few opposition members. The Malaysian political scenario of the late 1990s becomes the background of this novel. Political leaders from the ruling party are represented by Ariffin, Mahmud, Muhammad Noor, Abdul Kadir Jelani and Subramaniam. Seng Giaw is the only political leader from the opposition. As stated in the novel, the goal of every elected political leader is to be appointed by the Prime Minister as a cabinet minister (Affifudin 2011, 15). In other words, a political position associated with policy and decision-making is the main goal of the political leaders, even from the opposition. As a result, a few crucial questions arise: Is it alright for political leaders to harbour such ambitions, and why? How do they attain the position? How does a Prime Minister appoint political leaders to become cabinet members? These questions reflect the critical thoughts that would probably be raised by readers of the novel. To answer these questions, The Prince contains some political mottos or maxims that can be used as reference in discussing Paradoks.

Ariffin who originates from a village in Kedah (one of the 13 states in Malaysia) served in the corporate world, based in Kuala Lumpur before he quit and stood as a political candidate for UMNO in the general election. Ariffin is a political leader with a solid grounding in Islamic education and is well-educated. His father was a progressive religious teacher who taught al-Quran classes (Affifudin 2011, 13). Prior to his political involvement, as a corporate figure, Ariffin is knowledgeable in stocks and shares. So he was involved in the sales and purchasing of shares. The profits obtained were used to fund the needy and fulfil the desires of his wife who loved the luxuries of life. Unlike Ariffin, Mahmud, a Member of Parliament from Seremban, Negeri Sembilan has only a diploma and he only learned about the Islamic tenets when he joined an Islamic missionary. 
Mahmud has long been a "backbencher" in Parliament with Ariffin. He wishes to be rich and politics is a tool towards achieving his aspirations. After four years as an ordinary Member of Parliament, he is appointed as a Parliamentary Secretary in the Ministry of Works. After becoming a Parliamentary Secretary in the Ministry of Works, Mahmud begins to concretise his ambition to become a rich man. So he uses his political position to enrich himself and his family. In the eyes of society, Mahmud presents himself as a responsible and honest Parliamentary Secretary, not a political leader who takes advantage of his political position. He introduces himself as a political leader who has no personal interest in the development projects awarded to successful contractors. For instance, prior to the appointment of the Parliamentary Secretary, Mahmud was the Chairman of a construction company owned by Kadir Jelani, also a member of Parliament from the east coast. Upon his appointment as Parliamentary Secretary, Mahmud quits his corporate post in order to conceal his personal interests in the construction company. However, in reality, Mahmud has vested interests in projects approved by his ministry for his crony Kadir Jelani and his business partner, Edward Lim. Many development projects acquired by Edward Lim's construction companies shared Mahmud's interest. In return, Mahmud was paid commissions for the approved projects and the commissions were put into an account abroad by Kadir Jelani.

Here, the term commission is actually an euphemism for bribe or corruption. Accepting bribes have thus become a part of Mahmud's lifestyle. His position has provided Mahmud with power, especially in awarding contracts for government projects under his ministry. According to Lord Acton, a famous British political master, "Power tends to corrupt. Absolute power corrupts absolutely" (Ahmad Zaki 2001, 5). Mahmud is so powerful in his ministry since he was given a political position and political power. As a result, Mahmud became very corrupted. The practice of corruption has become embodied in the personality of such politicians and poses a structural problem with the system of government. It has also become a cultural issue, because there is a collective norm that has been accepted into the worldview of the people in various social environments. Corruption in all forms such as bribery, nepotism and extortion, is a major cause of the dehumanisation and victimisation of innocent people. Yet there is no sense of outrage and shame against this phenomenon among the elite. According to Syed Hussein Alatas, there are three stages of corruption. In the first stage, it is relatively restricted and does not affect a wide area of social life. Then, it becomes rampant, and thirdly, it becomes self-destructive (Syed Hussein 1995). According to the situation narrated in this novel, corruption in Malaysia has reached its third stage to the point where it has become self-destructive. 
Kadir Jelani is another Malay politician who is very corrupt. He uses Mahmud to secure government contracts and make tons of easy money. His connection with political leaders such as Mahmud has presented him with endless opportunities to accumulate illicit wealth easily, and this enormous wealth is kept in banks outside the country to avoid detection by the authorities. Money laundering has become part of his dirty political task due to the use of the Machiavellian political manual as subscribed by Mahmud. Kadir Jelani works for Edward Lim, who is involved in illicit activities such as gambling and prostitution. $\mathrm{He}$ is bribed by Edward Lim to ensure no actions were taken on these illicit activities.

Mahmud is not only a corrupt leader, but also immoral. He is a political leader who has two sides. His public persona is different from the hidden one. Politicians who act like Mahmud are practicing yet another of the principles of the Machiavellian political manual, which states that successful political leaders should portray themselves as having good values. Machiavelli says:

Therefore, it is unnecessary for a prince to have all the good qualities I have enumerated, but it is very necessary to appear to have them. And I shall dare to say this also, that to have them and always to observe them is injurious, and that appears to have them is useful; to be reflected merciful, faithful, humane, religious, upright, and to be so, but with a mind so framed that should you require not to be so, you may be able and know how to change to the opposite. $(1974,99)$

To the rest of the world, a political leader such as Mahmud should be perceived as clean, righteous and serving the people. Yet it is all just a facade and this superficial image may change at any time when needed. According to Machiavelli, a politician should be like Mahmud who can switch image at any time for his own convenience. Obviously, Mahmud practices the principle of the Machiavellian political manual. He is able to switch from the image of a clean politician to a sinner, when the need arises without any feelings of guilt. Mahmud abuses his political power for his own personal gain without any feelings of embarrassment. With this Machiavellian principle, he can remain in power. Mahmud and his colleagues represent the typical Malay political leaders in modern Malay politics, where politicians like Affifuddin were part of the ruling party.

It is not surprising that Mahmud, who does not have a strong religious background as Ariffin, would subscribe to image switching at his convenience. Mahmud believes that in Islam it is alright to commit sin and perform good deeds at the same time. For instance, although Mahmud already has two wives, he still flirts with another woman, Catherine Chin. For Mahmud, having two different 
characters is alright, and he proudly explains adultery to Catherine when she sees him praying after fornicating with her, "Oh! Don't be surprised; I subscribe to the principle that oil and water do not mix. I commit sin, and at the same time, I pray. My sincere devotion will scrape off all my sins!", said Mahmud (trans: Affifuddin 2011, 10).

Besides Mahmud and Kadir Jelani, who take Islamic teaching for a ride, Dr. Azizan is another politician who uses Islam for his own benefit. Dr. Azizan has been appointed by the Prime Minister to look after Islamic affairs, but later went against Islam. Dr. Azizan was educated at the Al-Azhar University in Egypt. He has been appointed as a Minister in the Prime Minister's Department to take care of the Ministry of Religious Affairs, in particular, Islam. This religious leader has flaunted himself as a Muslim leader who believes in God and acts according to Islamic teachings. In his speech, Dr. Azizan says, "Ladies and gentlemen! We need to know more about our culture that holds fast to the teachings of Islam over the past 500 years ago ... our nation will not compromise in administering the law" (trans: Affifuddin 2011, 86).

As a politician, Dr. Azizan needs to impress upon the people that he will defend the teachings of Islam, which are so deeply ingrained in him and he will not compromise with those who go against his principles. However, political power has made Dr. Azizan compromise his principles for position and gain. The problem here is, how does a political leader with a clear Islamic religious background also abused his position and the trust of the people who have elected him? In Paradoks, political leaders who protect the sanctity of Islam behave just like Mahmud, abusing their positions of political power. Dr. Azizan and Mahmud are not any different.

Just like Mahmud, Dr. Azizan practices image switching. This image switching can be seen on one occasion when Mahmud and Rosmini were caught together in a room at the King's Hotel by the Islamic Religious Department authority. They failed to produce any proper marriage documents. In Islam, it is not allowed for men and women who are not married to stay in secluded places such as in a hotel room because this will eventually lead to immoral activities such as adultery. So, in terms of Islamic law, Mahmud and Rosmini are guilty and action should be taken against them. This Islamic Religious Department authority was empowered by the ministry headed by Dr. Azizan to avert adultery among the Muslims. Such accusations would have serious consequences on Mahmud's political career, and on the Malaysian government as well. On this occasion, Dr. Azizan, the Minister of Religious Affairs is asked by Ariffin to release Mahmud from the charge of adultery. Dr. Azizan grants Ariffin's request for the release of Mahmud. With a phone call to a cleric named Mazlan who led the raid, Mahmud and his partner were released. In other words, Dr. Azizan's assistance in this matter is clearly a form of support for an immoral act. This act contradicts 
Islamic teachings as reflected in the Qur'an (Surah al-Mu'min, verses 19), which calls for Muslims to uphold righteousness, piety and not evil (Ahmad Zaki 2001, 1). Dr. Azizan is no different from the religious authorities who act as enforcers of Islamic law, such as the cleric Mazlan who is easily bribed. The author tells how corrupted cleric Mazlan and his friends are after they have been bribed:

"This reward is for you, as requested for the release of Mahmud and Rosmini," Yahya says.

Thank you! This is not for me alone. The members of my team should be rewarded too, cleric Mazlan took the envelope containing the money! (trans: Affifuddin 2011, 86).

Paradoks thus shows its readers how the religious institution is so corrupted. From top to bottom, all of them have abused the power entrusted in them. Dr. Azizan is a political leader who is responsible for Islamic affairs, and would appear to believe in the teachings of Islam, but this pious image is only skin deep. A politician such as Dr. Azizan is portrayed as a Muslim who practices Islamic values, but in reality, he does not. Thus, these people can change or switch their political image for certain reasons such as cronyism and for personal gain. Islamic values have therefore been overtaken by other factors, such as money.

From another aspect, according to Machiavelli, a political leader who wants to succeed, should act in accordance with the current development:

I believe he will also be successful, that's who directs his action according to the spirit of the times, and that's he whose actions do not accord with the times will not be successful. Because men are seen, in affairs that are which lead to the end every man has before him, namely, glory and riches, to get there by various methods; one with caution, another with haste; one by force, another by skill; one by patience, another by its opposite; and each one succeeds in reaching the goal by a different method. (1974, 140-141)

In the context of Paradoks, the mainstream political leaders do not care to distinguish between good and bad or between clean and unclean ways. According to the Machiavellian political manual, the ends are more important than the means. The Machiavellian maxim states "the end justifies the means" is clearly practiced in this context. The individual is more important than the state and God. The people as the voters are only the tools towards achieving the goal. Religion is a means to camouflage and legitimise desire. Morality is ignored. The means do not matter as long as the goal can be achieved. Political leaders like Mahmud and Kadir Jelani, who desire power and wish to stay in power have to adapt to 
the situation. They are willing to rise to power by employing dirty tricks. For these leaders, acquiring political power is an opportunity to become super rich and that is the only goal in life. No matter what the means, the most important is the goal. If political leaders go against the current leaders, they will be dropped out of the mainstream. Ariffin is a political leader who does not follow the spirit of the time. In Paradoks, Ariffin's political friends, especially from the ruling party are practicing despicable methods to become successful such as defamation and corruption. However, Ariffin does not agree with these methods.

As a political leader of the ruling party, the status of an ordinary Member of Parliament (without cabinet post) indicates a failed politician or a doomed failure as perceived by Ariffin's wife, Noraini. She found her husband had failed to realise her dream of becoming a cabinet minister's wife with wide ranging benefits in terms of money and status. Being a cabinet minister equates to power and glory. Ariffin however wishes to be appointed as a cabinet member the right way, such as based on excellent performance. Ariffin does not want the ends to justify the means. He does not want to follow the tricks of his friends and leaders of the ruling echelon such as Azrai and Husin Merican whose goals overcame the means. Ariffin does not want to succumb to Machiavellian politics. Ariffin explained to his wife why politicians do all sorts of immoral activities like defaming colleagues in the same party and not against the opposition:

The reason for politicians is to rise to high positions in the party and from there try to get jobs in the government or secure lucrative projects from the ministries. Their struggle in the party is not for a common noble goal, but in their own interest. (trans: Affifuddin 2011, 219-220)

Within the context of the Machiavellian political manual, Ariffin has failed to be a successful politician because of his commitment to principles that are based on religion and moral values. Ariffin shows that he is still one of the few ruling party politicians who still adheres to noble principles. Noraini is disappointed in her husband's stance. Ariffin's attitude is been criticised by his wife, and she desperately forces her husband to change, "Go and see the Prime Minister or your friends who are ministers! Then ask to become a chairman of any statutory body or whatever!" raged Noraini. "I know it is against your principles!" This what Ariffin has to say to his wife, "Begging is not my way! If they want to give me a position based on merit, I will accept it. If not, it is okay with me!" says Ariffin.

In response to Ariffin, Noraini still could not accept her husband's principle, "Principle, principle! In this world, we will not be successful living with such principles!" snapped Noraini (trans: Affifuddin 2011, 198). Strictly, according to Machiavellian political manual, politicians likes Ariffin are faced withdoom. 
In Paradoks, merit is no longer a benchmark even for a national leader. The question of value is not applicable in choosing political leaders to head a ministry in Malaysian politics. Specific ability or expertise in a field is not considered a benchmark for choosing political leaders. Ariffin, a political leader with a good academic qualifications in economics and business from renowned overseas universities is not viewed as an asset in solving the economic crisis which struck the Malaysian economy at that time. Instead, those who were capable to debate with the opposition were appointed. Intelligent and smart political leaders were not even considered to be appointed. This manner of appointing cabinet ministers disappointed Ariffin.

In a meeting between the supreme leader (probabily the 7th Malaysian Prime Minister) with his subordinates, a question was posed about the selection of his cabinet ministers. This is what the supreme leader says:

The main reason why I appointed the three backbenchers was because they are known as the members of Parliament of our party who vehemently deny any issues raised by the opposition. If I were to appoint a backbencher, such as Ariffin, most probably he will agree to proposals put forth by members of the opposition! (trans: Affifuddin 2011, 31)

The lower ranking leader gives his opinion, "Oh yeah! So the wise men are not quite worthless in politics in this country!" Supreme leader replies, "Don't you worry, everything can be handled by our officers in a neutral bureaucratic political stance. They are our, 'servants.' Not need to rely on fellow political leaders who are knowledgeable" (trans: Affifuddin 2011,32).

These exchanges reflect the attitude of the supreme leader himself, who no longer applies meritocracy in selecting his cabinet ministers. They are appointed not based on merits but on poor qualities. In other words, according to Ariffin, merit is not an important criterion in political leadership in Malaysia. Everything is based on the importance of the purpose, and the means can be anything. As can be seen, Ariffin is a political leader who does not follow the will and the way in time. Therefore, principled politicians like Ariffin who wants to serve the people can no longer remain in politics in Malaysia, as they fail to follow the instructions in the Machiavellian political manual.

Another element that is used for the selection of cabinet ministers is nepotism. Muhammad Noor, a Member of Parliament from Selangor has been appointed as the Minister of the Prime Minister Department because he has family connections with the Prime Minister's wife. He is the nephew of the Prime Minister's wife (Affifuddin 2011, 24). By subtracting merit and practicing nepotism, the quality and calibre of political leaders in Malaysia have collapsed. Consequently, the political leadership of Malaysia is doomed with various problems such as corruption, abuse of power and negative elements. 
The culture of slandering among Malay leaders in the ruling party is also very apparent. Slandering has become a way of life in the ruling party. What is slander? Slander is a statement, whether written or oral, temporary or permanent, affecting the reputation of others by making hated, despised or ridiculed that has resulted in making the victim less respected by the sensible society (Salleh 1994, 1). In Islam, slander is a big sin that is forbidden by God. According to the Qur'an in Surah al-Baqarah, verse 191, "slandering is more cruel than killing" (Bachrul 2007, 115). In Paradoks, Ariffin was being slandered by those who did not like him. Political leaders who wanted to be nominated as candidates for the next general election bribed the party staff at the party office such as Badri and Bakar to defame Ariffin. They made false accusations against political leaders who have the potential to be elected as good candidates like Ariffin. According to the novel:

The culture to humiliate those who do not share their aspirations will be like scabies in the party. Ariffin has been a victim since the first term of his membership of Parliament where he was slandered to have impregnated an eighteen-year-old girl. He wonders why people like Mahmud, Mohammad Noor and Kadir Jelani never been humiliated as they have done to him? (trans. Affifuddin 2011, 219)

The culture of slandering thus becomes a political weapon to discredit opponents. Slandering among political leaders in the same party is prevalent. The issue of sex is the most effective defamatory or slandering weapon. According to Ariffin, several individuals at the party office were used by certain leaders to create a political conspiracy to spread lies to discredit leaders who were not in agreement with them. One of these conspiracies would be accusations of unnatural sex acts. This tactic becomes a hot topic for members of the Malay community, and they are quite sensitive and interested in sexual issues compared to other more important issues, such as corruption and abuse of power by those holding higher authorities (Affifuddin 2011, 60). In other word, slander is a political strategy to succeed among Malaysian politicians who practiced the Machiavellian political manual, which contravenes Islamic teaching.

Noraini who is unconsciously influenced by the Machiavellian political manual did worse, by having an affair with another man when Ariffin went to Germany for treatment of prostate cancer. She did it as a form of protest against her husband whom she believes is insincere to her. She believes that Ariffin has disappeared over an affair with his secretary. Noraini along with the wives of higher ranking officers and greedy politicians form a social group called tante girang. This group is a socialises outside the knowledge of their husbands, and tante girang activities are a symbol of a negative value system that occurs in the national politics of Malaysia. 
Sexual activities by tante girang and the portrayal of political leaders who are womanisers such as Mahmud present erotic elements in Paradoks. Noraini and other wives neglected by their husbands engage in activities with gigolos (gigolo refers to a handsome man who is willing to satisfy the sexual desires of age and lonely women). Noraini's sexual episodes with Adam Silkcock (even the name is an erotic element) have injected eroticism into the novel (Affifuddin 2011,333-334). Prior to these scenes involving Noraini, Mahmud the womaniser has also been portrayed as engaging in sexual activities with a Chinese woman, Catherine Chin. From the aspect of creative writing of this novel, what is the function of this erotic element? Is it included as a selling point of this novel, designed to enhance the reader's enjoyment? Is it meant to denigrate the dirty politicians who are corrupted to the core and the rampant abuse of political power? Or is it to minimise the impact of political criticism of this novel on Malaysian politics, especially the ruling party where Affifuddin the author of this novel is a member of the party? As the analysis progresses, these three assumptions can be considered as the true purpose of the erotic elements in this novel.

In Islam, Noraini's sexual activities are against the teaching and practice of Islam, but her behaviour is not different from the activities of the Muslim Malay political leaders such as Mahmud, Kadir Jelani and Dr. Azizan, who are corrupted and abuse their political power. However, the Malays are more interested in sex, and they would become over sensitive in this matter. This is the greatest paradox in the Malay community as reflected in this novel. At the end of this novel, Affifuddin punished the corrupt political leaders and those who abuse political power, but he lets Noraini and Mahmud build a new life after they have repented. Kadir Jelani was to be brought to court and charged with money laundering because he worked and acted as a mule for Tan Sri Edward Lim's illicit money. This money was used to bribe political leaders who were viewed as potential future leaders, such as Ariffin. Kadir Jelani and Edward Lim were sentenced to jail.

In this novel, poison pen letters (surat layang) became the medium used as a political tool to spread lies, slander or sensational news. The use of poison pen letters looks like a conservative political medium, but it is an effective political tool in creating a strong impact against the victim. Ariffin has been the victim of these poison pen letters (Affifuddin 2011, 219). This method was used as a strategic political tool by the members of the same party. It is one of the more practical and realistic scenarios depicted in the novel. The unethical attacks against Ariffin by his own friends is regarded as similar to a friendly fire in a political party setting rather than a real political enemy. Thus, for the author, it is more appropriate to use poison pen letters compared to other media such as newspapers or television. In another context, during the era of Mahathir Mohamad's rule as the Prime Minister, a wide range of media tools such as television, radio, newspapers and 
internet was employed in the service of the hegemonic practice (Noor Sulastry 2014). This is the larger political picture which encompasses the ruling party and the opposition compared to what is in the novel. So during the era of Mahathir Mohamad, the use of the media should be viewed in the wider perspectives because it covers a broad range of issues and targeted different audience, yet this was deemed unsuitable in the context of Paradoks.

\section{CONCLUSION}

As reflected in the title of the novel, Paradoks shows paradoxes within the context of partisan politics. In the context of hegemonic practice, the ruling party seems to be dominating the government and this has made the political leaders forget their responsibilities as elected politicians towards the people who are supposed to be the protected and governed group. There is no check and balance from the opposition parties because they are too weak and ineffective to provide strong criticisms. The Malay political leaders and Malay people are Muslims, but their actions do not reflect the teachings of Islam. Corruption and misuse of political power have been practiced beyond the religious and moral behaviour in order to achieve specific personal goals for the Malay politicians. The Malay community also contributes to this problem by being quicker to react to sexual issues rather than corruption and abuse of political power. This form of thinking is also part of the government's political strategy. Consequently, they are directly involved as breeders and cultivators of negative political governance. In Paradoks all these are intertwined to reflect on the application of Machiavellian political manual by the Malay politicians. The principle of "the end justifies the means" or "politics have no relation to morals" has become an important element of the Machiavellian politics practiced by the Malay politicians. The Malay people are more receptive to the unnatural sexual innuendos, compared with issues of corruption and abuse of power. Islam is no longer a form of defence against corruption and abuse of power, but a mask utilised for a leader who wishes to be seen as bertaqwa or pious. They easily take off this mask when the need arises. The author believes that a deep and correct understanding and appreciation of Islam are required to get rid of the Machiavellian political manual principles. The use of media is also significant in contributing to the culture of slander. Poison pen letters are more effective for slander, especially when it involves friends who turned out to be his political enemies. Being a human, Ariffin also has weaknesses, yet he still able to defend his principles as a political leader to fulfil the people's trust and not for his personal gain. His Islamic background has contributed a lot in making him a tough politician in combating corruption and negative political activities and yet, only a handful of political leaders practise the balance between religion and politics in 
theory and practice, such as Ariffin. Affifuddin's experience as a politician within the hegemonic environment of Malaysian politics becomes the raw material for his novel. He is not only telling his readers what they already know, but enabling them to ponder upon what was going on behind scenes in the political milieu during which the novel was set. With Machiavelli's political manual as an analytical tool, readers will be able to contemplate the message conveyed by this novel.

\section{REFERENCES}

Affifudin Omar. 2011. Paradoks. Kuala Lumpur: Dato’ Wira Dr. Affifuddin Haji Omar. Ahmad Zaki Hj Husin. 2001. Pembenterasan jenayah rasuah di Malaysia. Siri syarahan umum bil. 12. Pulau Pinang: Penerbit Universiti Sains Malaysia.

Arba'ie Sujud, Salihahs Razak and Siti Rabiatul Adawiah Jaffar. 2015. Pemikiran politik: Pemimpin dan kepemimpinan dalam novel Shahnon Ahmad. International Journal of the Malay World and Civilization 3(1): 67-78.

Bachrul Ilmy. 2007. Pendidikan agama Islam, jilid 3. Bandung: Grafindo Media Pratama. Badan Pencegah Rasuah Negeri Pahang Darul Makmur. 2000. Rasuah dihina, maruah dibina. Pahang: Badan Pencegah Rasuah Negeri Pahang Darul Makmur.

de Mesquita, B.B. and A. Smith. 2012. The dictator's handbook: Why bad behavior is almost always good politics. New York: The Perseus Books Group.

Machiavelli, N. 1974. The Prince. Translated by W.K. Marriot and Introduction by H. Butterfield. London: Everyman's Library.

Muhammad Kamlin. 1986. Pengantar pemikiran politik Barat. Selangor: Penerbit Universiti Kebangsaan Malaysia.

MyKedah. 2014. Anak-anak Kedah: Dato' Dr. Affifuddin Haji Omar. http://www .mykedah2.com/20hall_fame/202_9_03.htm (accessed 10 July 2014).

Noor Sulastry Yurni Ahmad. 2014. Hegemoni budaya politik Melayu. Selangor: Penerbit Universiti Kebangsaan Malaysia.

Roslan Chin. 2005. Memahami kematian dalam novel-novel terpilih Shahnon Ahmad melalui kod budaya dan simbolik: Satu kajian semiotik. Master's diss., Universiti Sains Malaysia.

Salleh Buang. 1994. Undang-undang fitnah di Malaysia dan Singapura. Kuala Lumpur: Dewan Bahasa dan Pustaka.

Sohaimi Abdul Aziz. 2014. Novel dalam kritikan. Pulau Pinang: Penerbit Universiti Sains Malaysia.

Syed Hussein Alatas. 1995. Rasuah: Sifat, sebab dan fungsi. Kuala Lumpur: Dewan Bahasa dan Pustaka.

William, C. 1981. Appearance and reality in politics. Cambridge: Cambridge University Press.

Zabidin Ismail. 2010. Pemikiran politik dalam novel Ahmad Boestamam. Kuala Lumpur: Penerbit Universiti Malaya. 